\title{
Microstructure of Thermally Modified Radiata Pine Wood
}

José Luis Cabezas-Romero, ${ }^{a}$ Linette Salvo-Sepúlveda, ${ }^{a}$ Helga Contreras-Moraga, ${ }^{a}$

Natalia Pérez-Peña, ${ }^{a}$ Víctor Sepúlveda-Villarroel, ${ }^{a}$ Maximilian Wentzel, ${ }^{a}$ and

Rubén A. Ananías ${ }^{a, b, *}$

The thermal modification of wood is a potential alternative method for improving wood dimensional stability and increasing the resistance of wood to decay. However, during thermal modification, morphological changes occur within the microstructure of the cell, and these confer different properties to the wood. This study investigated the effects of the thermal modification process on the microstructure of radiata pine juvenile wood. Therefore, anatomical measurements were performed via optical microscopy in selected earlywood and latewood samples after each treatment, and the results were compared to untreated wood samples. In this study, two temperatures $\left(190^{\circ} \mathrm{C}\right.$ and $\left.210^{\circ} \mathrm{C}\right)$ were considered for the thermal modification process. The results showed that the level of temperature of modification affected to microstructure of cell wall. The cell wall thickness decreased as treatment temperature increased, whereas the average lumen diameter increased slightly as temperature increased. Thermally modified radiata pine showed signs of damage (cracks, broken cells and deformations in the wood cell wall). The proportion of destroyed area increased as temperature increased, and significant differences were evident for the thermal treatment at $210^{\circ} \mathrm{C}$.

Keywords: Cell wall thickness; Heat treatment; Juvenile wood; Lumen diameter; Thermal modification; Wood anatomy

Contact information: a: Research Laboratory of Wood Drying and Heat Treatments, University of Bio-Bio, Av. Collao 1202, Concepción, Chile; b: Department of Wood Engineering, Faculty of Engineering,

University of Bío-Bío, Av. Collao 1202,Concepción, Chile; *Corresponding author: ananias@ubiobio.cl

\section{INTRODUCTION}

The thermal modification of wood is performed at temperatures between $160{ }^{\circ} \mathrm{C}$ and $240{ }^{\circ} \mathrm{C}$ under varying operating conditions, such as steam, vacuum, or nitrogen (Hill 2006; Militz and Altgen 2014; Sandberg et al. 2017). The effects of thermal modification on the physical and mechanical properties of wood have been widely published (Kubojima et al. 2000; Yildiz et al. 2006; Hill 2006; Boonstra et al. 2007; Esteves and Pereira 2009; Esteves et al. 2014; Tasdemir and Hiziroglu 2014; Uribe and Ayala 2015; Sandberg et al. 2017, among others); however, from an anatomical point view the effects on cell structure have not shown clear trends (Boonstra et al. 2006a,b; Awoyemi and Jones 2011; Kekkonen et al. 2010; Welzbacher et al. 2011; Biziks et al. 2013; Batista et al. 2015; Bernabei and Salvatici 2016; Jiang et al. 2017). In addition, literature on the topic has been limited due to the difficulty of studying the effects before and after heat treatment on the same piece of wood (Kekkonen et al. 2010; Bernabei and Salvatici 2016; Wentzel et al. 2020).

The main advantages of thermal modification are reduced hygroscopicity and equilibrium moisture content, increased dimensional stability and permeability (Tjeerdsma and Militz 2005; Hill 2006; Esteves and Pereira 2009; Uribe and Ayala 2015), increased resistance of wood to natural weathering, and improved durability and decay resistance 
(Kamdem et al. 2002; Nuopponen et al. 2005; Welzbacher and Rapp 2007), decreased volumetric shrinkage and swelling, and hardness (Uribe and Ayala 2015).

During thermal modification, chemical changes occur within the structure of the cell wall, and these confer new characteristics and properties to the wood. Recently, Faraone et al. (2020) found that the thermal modification is also a strategy to improve the antioxidant activity of wood extractives. The degradation of the polymers and extractives of the cell wall occurs due to changes in chemical composition through different chemical reactions (Esteves et al. 2008). However, the mechanical properties of thermally modified wood tend to decrease (Kubojima et al. 2000; Yildiz et al. 2006; Boonstra et al. 2007). In addition, hardwoods show higher strength losses than softwood when modified under the same conditions (Hill 2006; Boonstra et al. 2007).

The anatomical structures of wood can be modified depending on certain treatment parameters, such as temperature, process duration, heating rate, and wood species (Boonstra et al. 2006a; Poncsák et al. 2006). The degradation of the polymers and extractives of the cell wall occurs due to changes in chemical composition through different chemical reactions (Esteves et al. 2008). According to Jiang et al. (2017), differences in the distribution of surface chemical composition can produce different cell wall fractures (predominantly at the middle lamella) as well as a lost moisture content, resulting in defects, such as collapse, cracks, and deformations (Boonstra et al. 2006a), because wood mass, dimension, and the shape of the wood cells begin to change when increases or decreases the wood moisture content. It has also been found that these changes are related to the temperature, drying time, and drying rates, among other (Reiterer and Tschegg 2002; Redman et al. 2016; Jiang et al. 2017; Zhang et al. 2018, Nopens et al. 2019). After heat treatment, Uribe and Ayala (2015) observed differences in shape and size of the pore, as well as a significant deterioration in the cell wall appearance.

Kekkonen et al. (2010) observed that lumens' dimensions decrease in the three directions during thermal modification of Pinus sylvestris. They also indicated that around $200{ }^{\circ} \mathrm{C}$ (critical temperature), the pore size begins to increase because of the decomposition of the cell walls. Hietala et al. (2002), observed that increase or decrease pore size depends on the wood species and modification process.

Awoyemi and Jones (2011) reported that the destruction of tracheid walls and ray tissues occurred during the heat treatment of red cedar wood. In addition, the authors concluded that the changes in anatomical structure could have contributed to the changes in wood properties. Likewise, a scanning electron microscopic analysis of heat-treated beech and spruce wood indicated that heat-induced defects in their microstructure contribute to the strength loss of thermally modified wood (Welzbacher et al. 2011). This was also confirmed by Biziks et al. (2013), who studied the effect of heat treatment on the microstructure of birch wood. They concluded that the changes in the microstructure differ noticeably depending on the thermal treatment conditions and the type of the cell, as they observed a peak decrease of $37 \%$ of the fiber wall area after modification at $180{ }^{\circ} \mathrm{C}$. Bernabei and Salvatici (2016) studied the anatomical characteristics of spruce wood during heat treatment using an environmental scanning electron microscope. They found that cell wall thickness decreases at high temperatures. In addition, their results indicated apparent differences between latewood and earlywood cell walls size, but the differences were not confirmed statistically. Lin et al. (2017) studied the effect of thermo-vacuum treatment on the anatomical characteristics of Szemao pine and alder birch wood. For Szemao pine, small radial cracks were observed, and some ray parenchyma cells were destroyed. For alder birch wood, the anatomical structures were almost unaffected. Based on these results, 
the authors concluded that the thermo-vacuum treatment had a slight effect on the anatomical structure without causing serious damage. In their study of thermally modified Scots pine at $180{ }^{\circ} \mathrm{C}$, Kymäläinen et al. (2018) showed that delamination and damage in the cell walls occurred, and radial cracks close to the tracheids were present in the earlywood.

In contrast, some studies, such as that performed by Andersson et al. (2005), on the thermally modified wood of Pinus sylvestris, have reported that thermal modification did not lead to a change in anatomical structure. Likewise, Batista et al. (2015) reported that thermal modification did not significantly affect the structure of the ray parenchyma, vessels, or fibers of Eucalyptus grandis wood. In addition, no significant changes were observed in fiber dimensions. Recently, Wentzel et al. (2020) investigated the anatomical characteristics before and after thermal modification of Eucalyptus nitens wood in open and closed systems. Their results showed that there were no noticeable differences in anatomical structure between the two modification systems, and there were only slight changes in the cell wall thickness and fiber and lumen areas after thermal modification.

In this study, the microstructure thermally modified radiata pine juvenile wood was analyzed focus on visualizing and quantifying exploratory the morphological changes after thermal modification.

\section{EXPERIMENTAL}

\section{Materials}

For the experiments, dried sawn wood of radiata pine (Pinus radiata D. Don) from a 26-year-old plantation in the Bio Bio region of Chile was utilized. The core-wood (juvenile wood) was sawn in boards of $25 \mathrm{~mm} \times 100 \mathrm{~mm} \times 3200 \mathrm{~mm}$ (width, thickness, and length, respectively). The sawn core-wood was dried in a chamber (Model Lab3.5e, Neumann, Concepcion, Chile) using a drying schedule at $100{ }^{\circ} \mathrm{C} / 70{ }^{\circ} \mathrm{C}$ (dry bulb / wet bulb) with an airflow speed of $6 \mathrm{~m} / \mathrm{s}$. The temperatures inside the chamber were monitored, and the temperature and moisture content of the wood were recorded according to the setup and kiln schedule.

\section{Methods}

Thermal modification process

Laboratory-scale thermal modifications at $190{ }^{\circ} \mathrm{C}$ and $210{ }^{\circ} \mathrm{C}$ were made using the kiln-dried wood. An initial load of 140 samples was evenly stacked and placed in equidistant layers separated by sticks of $20 \mathrm{~mm}$ in thickness. The tests were realized in a flexible industrial prototype chamber with a capacity of $3.5 \mathrm{~m}^{3}$ (Model Lab3.5e, Neumann, Concepcion, Chile) designed to withstand temperatures up to $250{ }^{\circ} \mathrm{C}$. For each process, the chamber was loaded with 140 samples according to the schedules implemented by HerreraDíaz et al. (2019). The first phase of the modification process began with a fast increase to temperature to $100{ }^{\circ} \mathrm{C}$. In the second phase, the temperature was increased at a rate of 0.7 ${ }^{\circ} \mathrm{C} / \mathrm{min}$ until reaching $190^{\circ} \mathrm{C}$ or $210^{\circ} \mathrm{C}$. During this stage, the wood was sprayed with steam to avoid damage. At the end of the second phase, the wood reached a moisture content of $3 \%$ to $4 \%$. Subsequently, the temperature $\left(190{ }^{\circ} \mathrm{C}\right.$ or $\left.210{ }^{\circ} \mathrm{C}\right)$ was maintained for approximately $3 \mathrm{~h}$. In the final step, the samples were cooled and stabilized for approximately $5 \mathrm{~h}$ to $7 \mathrm{~h}$. The total time of thermal modification was approximately $32 \mathrm{~h}$, and the final wood moisture content ranged from $9 \%$ to $11 \%$. 


\section{Anatomical measurements}

For studying effects of heat treatment on wood, before the thermal modification process 152 sawn low-quality core-wood pieces (juvenile wood) were selected, 12 as control pieces $(\mathrm{Ctrl})$, and 140 for the thermal treatment. From the process, 12 pieces were randomly selected when the $190{ }^{\circ} \mathrm{C}$ (T1) procedure was finished and then another 12 pieces when the process reached the temperature of $210^{\circ} \mathrm{C}(\mathrm{T} 2)$. Anatomical measurements were performed at the Wood Anatomy Laboratory of the University of Bio-Bio (Concepción, Chile). Following the methodology described by Chaffey (2002), a cube from each piece was cut and soaked in water for $36 \mathrm{~h}$. A transverse slice of $20 \mu \mathrm{m}$ was obtained using a Microm Model HM325 microtome (Thermo Fisher Scientific, Tampa, FL, USA) from each one of the 12 cubes, with emphasis paid to the positions of the annual rings when they were cut. Then, 12 slice were stained in safranin and mounted on a glass slide and cover glass using Canada balsam. The wood anatomical structure images were obtained using a Lumenera (Ottawa, Ontario, Canada) Infinity digital camera and analyzed via WinCell Pro (Regent Instruments Inc., v.2011a, Québec, Canada).

Wood cells morphological data were measured per annual ring. The exploratory research experiment was designed, considering the intra-ring variability. The experiment involved repetition (measurements on wood cells per annual ring) instead of replicability (measurements on multiple slices). In every slice, tracheid dimensions in the radial (R) and tangential (T) directions were measured in 16 randomly cells (8 early and 8 latewood cells) at the beginning of the annual ring from each sample. Secondary wall thickness ( $2 \mathrm{R}$ and 2 $\mathrm{T}$ measurements) and lumen diameter were evaluated. Length and width were measured as the horizontal and vertical size of the cell in its center of gravity position. From a grayscale image, thresholding were used to produced binary images for enhance cell contrasts when was acquired images (Fig. 1).

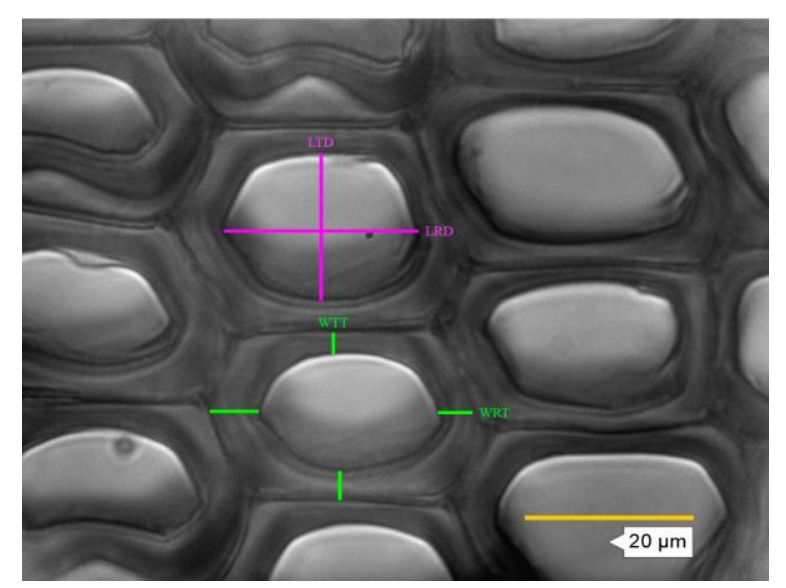

Fig. 1. Unmodified radiata pine (Pinus radiata) wood transverse surface of latewood 40x.

Lumen and secondary cell wall thickness measurements of tracheid (LRD: lumen radial diameter; LTD: lumen tangential diameter; WRT: wall radial thickness WTT: wall tangential thickness)

The effect of thermal modification on the microstructure was analyzed relative to the quantity of damage under different process conditions. Every image (magnification for imaging was $10 \times$, and the size of each image was $1468 \mu \mathrm{m}^{2}$ ) was subdivided into 6 subregions. Manual measurements were performed to determine the proportion $(\%)$ of cells with damage (gaps, tracheid wall destruction, cracked areas, cell breakage, and 
deformation or distortion of cellular structure) according to the protocols of the WinCell Pro software.

\section{Data analysis}

Kolmogorov-Smirnov and Barlett tests were performed to verify the normality of data distribution and homogeneity of variance among treatments. Analysis of variance (ANOVA) testing was performed to analyze the significant differences, and the means were compared between treatments via Tukey testing with a 95\% confidence level. The software Statistica (Statsoft Inc., v.10.0, Tulsa, OK, USA) was used to perform the statistical analysis.

\section{RESULTS AND DISCUSSION}

According to the F-test results of the ANOVA testing presented in Table 1, the treatments had a significant effect in cell wall thickness and lumen diameter of earlywood. For latewood, the cell wall thickness and lumen diameter of the unmodified and thermally modified samples were not statistically different, which indicates that the thermal modification treatment had no significant effect.

Table 1. ANOVA of the Treatment Levels on Cell Wall Thickness and Lumen Diameter

\begin{tabular}{|c|c|c|c|c|c|c|}
\hline \multirow{2}{*}{ Source } & \multirow{2}{*}{ D. F. } & \multirow{2}{*}{ Result } & \multicolumn{2}{|c|}{ Cell Wall Thickness } & \multicolumn{2}{c|}{ Lumen Diameter } \\
\cline { 4 - 7 } & & & EW & LW & EW & LW \\
\hline \multirow{2}{*}{ Treatment } & \multirow{2}{*}{2} & F-test & 20.68 & 0.88 & 8.03 & 0.11 \\
\cline { 3 - 6 } & & p-value & $<0.0001^{*}$ & 0.4168 & $0.0004^{*}$ & 0.8923 \\
\hline
\end{tabular}

Notes: D.F. = degrees of freedom; EW = earlywood; $L W=$ latewood; *significant at $p \leq 0.05$

The average cell wall thicknesses of the earlywood and latewood are shown in Fig. 2. For earlywood (Fig. 2a), the average cell wall thicknesses were $3.55 \mu \mathrm{m}, 3.36 \mu \mathrm{m}$, and $3.07 \mu \mathrm{m}$ for unmodified control samples $(\mathrm{Ctrl}), 190{ }^{\circ} \mathrm{C}(\mathrm{T} 1)$, and $210{ }^{\circ} \mathrm{C}(\mathrm{T} 2)$, respectively. Cell wall thickness tended to decrease as the temperature of heat treatment increased, which was similar to the results of Biziks et al. (2013), who investigated changes in the microstructure of birch wood after hydrothermal treatment at three different temperatures. They found the greatest changes after treatment at $180{ }^{\circ} \mathrm{C}$, which reached an average decrease of $32 \%$. However, treatment $\mathrm{T} 1\left(190^{\circ} \mathrm{C}\right)$ did not have a significant effect on cell wall thickness (the difference of means between Ctrl and T1 was not statistically significant). When the temperature was increased to $210^{\circ} \mathrm{C}$, cell wall thickness decreased significantly. The decreases in thickness were 5.3\% and $13.5 \%$ for T1 and T2, respectively. The average cell wall thicknesses of latewood (Fig. 2b) were $4.92 \mu \mathrm{m}, 4.87 \mu \mathrm{m}$, and 4.77 $\mu \mathrm{m}$ for Ctrl, T1, and T2, respectively, and the decrease in thickness was $1.02 \%$ for $\mathrm{T} 1$ and $3.05 \%$ for $\mathrm{T} 2$. The difference between treatments was not statistically significant at the 0.05 probability level. Bernabei and Salvatici (2016) examined the effect of heat treatment on the cell wall thickness of Picea abies and concluded that, from approximately $100{ }^{\circ} \mathrm{C}$ to $200{ }^{\circ} \mathrm{C}$, the dimensions remain almost constant, but a rapid decrease in thickness occurs at temperatures over $200{ }^{\circ} \mathrm{C}$. 

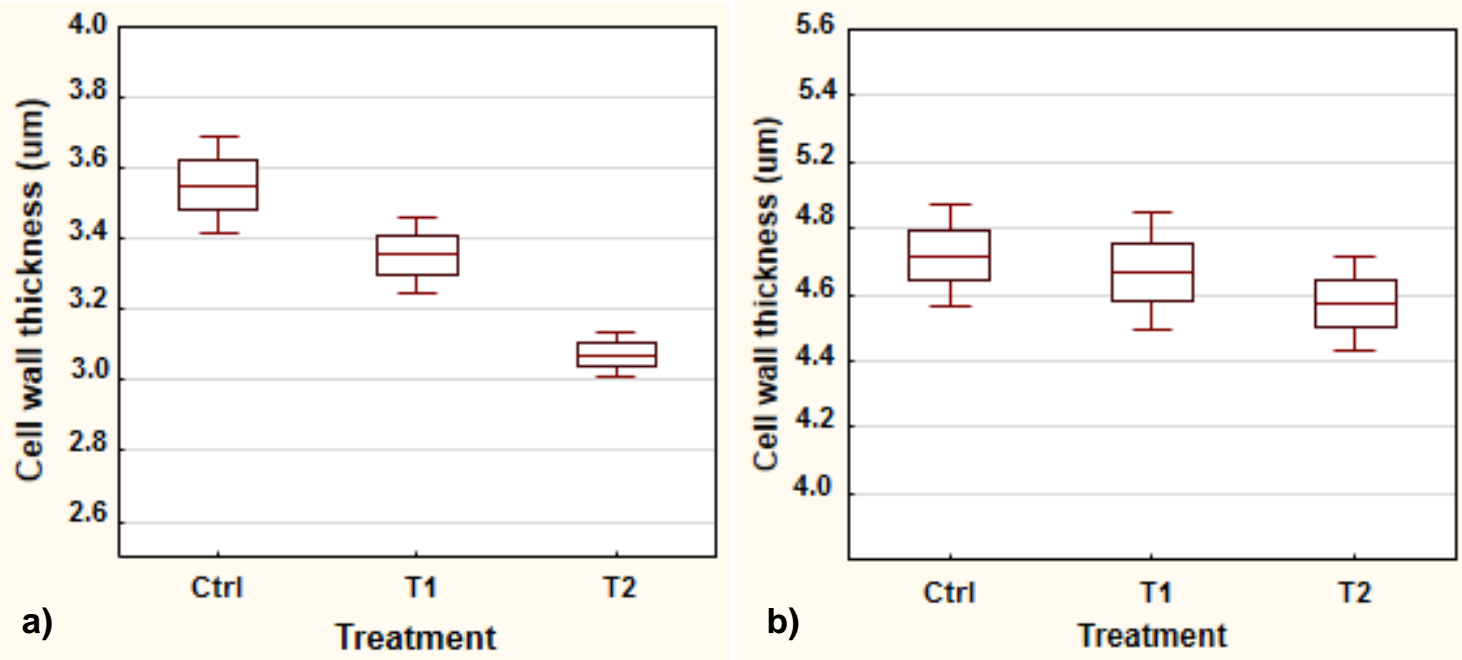

Fig. 2. Average values of cell wall thickness of unmodified control samples and thermally modified wood samples of (a) earlywood and (b) latewood

The results of the lumen diameter measurements showed a slight increase in diameter as temperature was increased (Fig. 3). For earlywood (Fig. 3a), the average lumen diameters were $32.46 \mu \mathrm{m}$ for $\mathrm{Ctrl}, 33.54 \mu \mathrm{m}$ for $\mathrm{T} 1$, and $35.09 \mu \mathrm{m}$ for $\mathrm{T} 2$, which corresponded to an increase of $3.3 \%$ and $8.1 \%$ for $\mathrm{T} 1$ and T2, respectively. Kekkonen et al. (2010) found similar results, which were attributed to the decomposition of the cell walls.
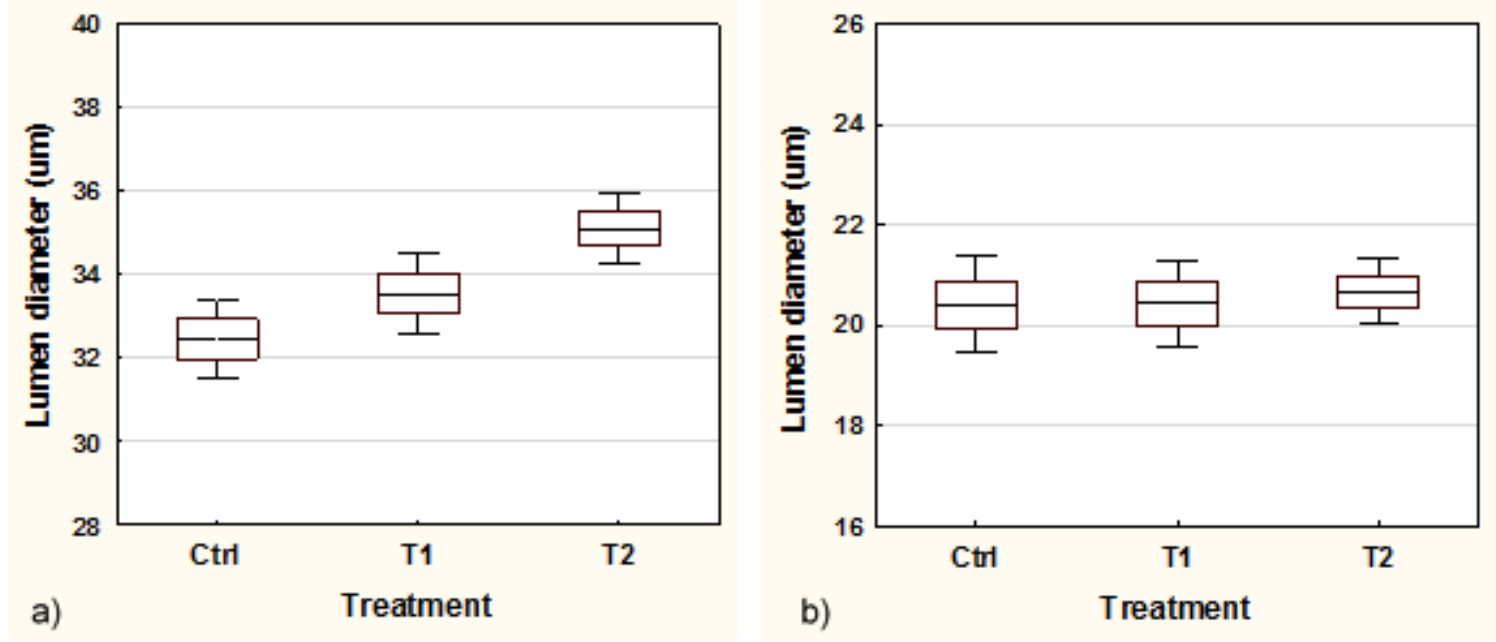

Fig. 3. Average values of lumen diameter of unmodified and thermally modified wood samples of (a) earlywood and (b) latewood

For latewood (Fig. 3b), the values were $20.41 \mu \mathrm{m}, 20.43 \mu \mathrm{m}$, and $20.66 \mu \mathrm{m}$ for Ctrl, T1, and T2, respectively. No significant differences were found between treatments. In all treatments, the difference between earlywood and latewood results were significant ( $\mathrm{p}<0.0001)$. Similarly, Bernabei and Salvatici (2016) reported average increases of lumen diameter in Picea abies wood of $6.2 \%$ and $1.8 \%$ for earlywood and latewood respectively, during heat treatment at $200{ }^{\circ} \mathrm{C}$.

The anatomical structures of thermally modified and unmodified radiata pine wood are shown in Fig. 4. The structures showed changes from the unmodified state. After 
modification at $190{ }^{\circ} \mathrm{C}$, a slight crushing of the cellular lumen in earlywood was observed (Fig. 4b). However, when the temperature was increased to $210^{\circ} \mathrm{C}$, more intense crushing of the cellular lumen was observed (Fig. 4c). In addition, small cracks, broken cells, and cell deformations in some areas on the cell wall of earlywood were observed after modification. In this direction, Boonstra et al. 2006a, found radial cracks along the tracheids of early wood in Scots pine, as well as distortion of cell structure has also been reported.

b)

a)

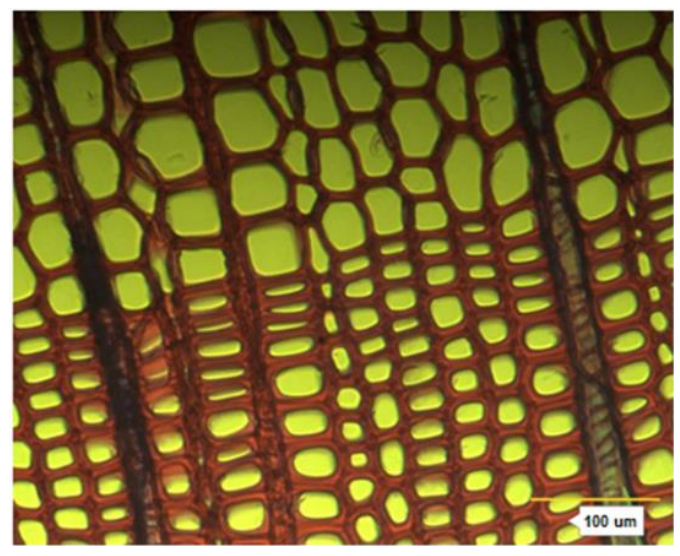

c)
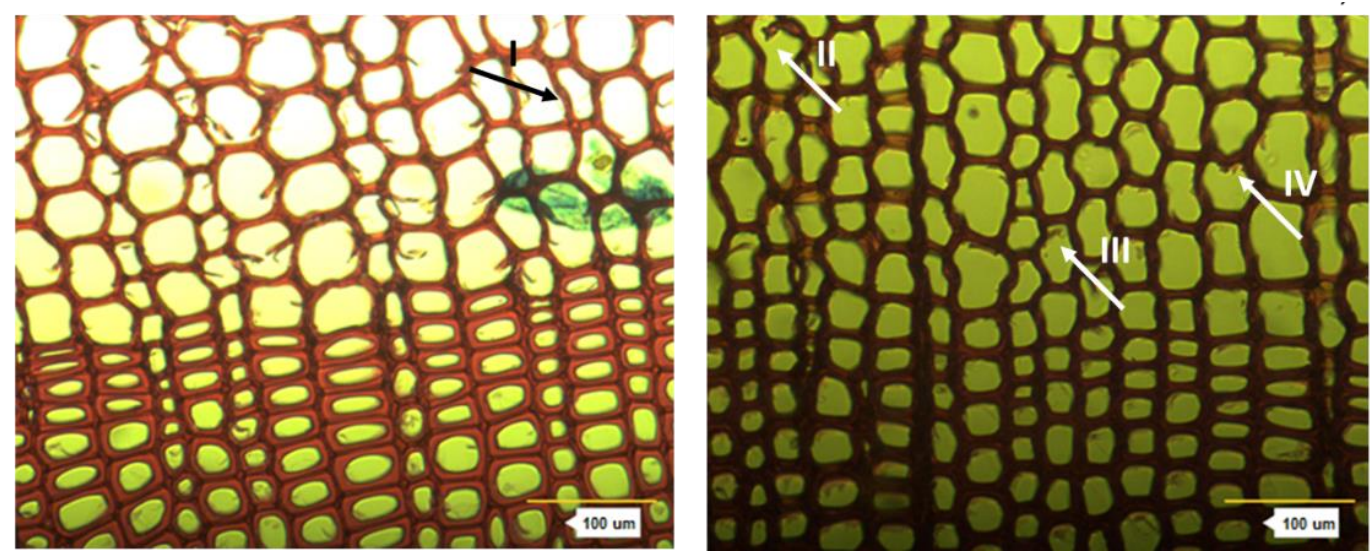

Fig. 4. Anatomical structure of thermally modified and unmodified radiata pine wood, with the arrows pinpointing the structural changes of the thermally modified wood: (a) unmodified wood; (b) thermally modified wood at $190^{\circ} \mathrm{C}$ (I: crushing); (c) thermally modified wood at $210^{\circ} \mathrm{C}$ (II: broken cells, III: small cracks, IV: cell deformations)

In quantitative terms and based on the measurements and the identified proportions of damaged cells, the damaged area increased as the temperature of thermal treatment increased (Fig. 5). The unmodified wood had a damaged area of $80.2 \mu \mathrm{m}^{2}$. According to Boonstra et al. (2016a), the earlywood tracheids of Norway spruce were slightly deformed for unmodified wood. In this context, damaged such as tracheid wall destruction, cracked areas, and cell breakage or deformation of cellular structure could be directly attributable to the preparation of the specimen, boiling and cut that can affect the condition of the wood (Bernabei and Salvatici 2016). 


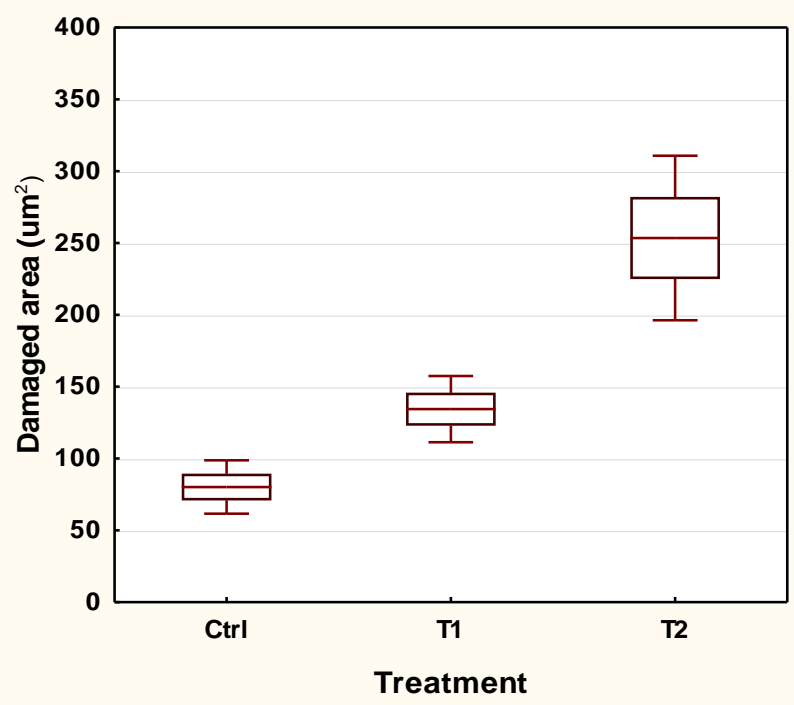

Fig. 5. Damaged area in the anatomical structure of thermally modified radiata pine wood for the unmodified wood (Ctrl), wood modified at $190^{\circ} \mathrm{C}(\mathrm{T} 1)$ and wood modified at $210^{\circ} \mathrm{C}(\mathrm{T} 2)$

The damaged areas of the thermal treatments at $190{ }^{\circ} \mathrm{C}$ and $210^{\circ} \mathrm{C}$ reached values of $134.4 \mu \mathrm{m}^{2}$ and $253.5 \mu \mathrm{m}^{2}$, respectively, which corresponded to an increase of $9.2 \%$ for T1 and $17.3 \%$ for T2. Similar results were found by Kymäläinen et al. (2018), who reported that the cell wall was damaged and delaminated at $180^{\circ} \mathrm{C}$ and $\mathrm{Gao}(2017)$, who observed formation of small cracks in latewood tracheids at $220^{\circ} \mathrm{C}$.

The difference between Ctrl and T1 was not statistically significant. Hietala et al. (2002) have reported similar trends, where the measurements showed no clear change in the cell dimensions of the thermally modified samples compared with control samples.

\section{CONCLUSIONS}

1. Thermally modified radiata pine showed signs of damage after the thermal modification process, as small cracks, broken cells, and deformations in the wood cell wall were present after modification. The cell wall thickness decreased and the average lumen diameter increased as the modification temperature increased.

2. The changes in the structure of the modified wood were more noticeable at modifications at $210{ }^{\circ} \mathrm{C}$. This was made evident by an analysis of the damaged area after modification that showed a statistically significant increase at this temperature, which means that the cellular structure was more affected as the modification temperature increased.

3. Further research should focus on defining whether the speed of the increase in temperature to reach the modification temperature could be a factor in the development of the changes in the cellular structure and to further analyze the development of cracks in the wood cell wall structure. 


\section{ACKNOWLEDGMENTS}

This research was funded by ViceRectoría de Investigación y Postgrado, University of Bío-Bío, Concepción, Chile. The authors are grateful for the support of the National Agency of Science \& Development of Chile (Fondequip EQM130236).

\section{REFERENCES CITED}

Andersson, S., Serimaa, R., Väänänen, T., Paakkari, T., Jämsä, S., and Viitaniemi, P. (2005). "X-ray scattering studies of thermally modified Scots pine (Pinus sylvestris L.)," Holzforschung 59(4), 422-427. DOI: 10.1515/hf.2005.069

Awoyemi, L., and Jones, I. P. (2011). "Anatomical explanations for the changes in properties of western red cedar (Thuja plicata) wood during heat treatment," Wood Science and Technology 45(2), 261-267. DOI: 10.1007/s00226-010-0315-9

Batista, D. C., Paes, J. B., Bolzon de Muñiz, G. I., Nisgoski, S., and da Silva Oliveira, J. T. (2015). "Microstructural aspects of thermally modified Eucalyptus grandis wood," Maderas. Ciencia y Tecnología 17(3), 525-532. DOI: 10.4067/S0718221X2015005000047

Bernabei, M., and Salvatici, M. C. (2016). "In situ ESEM observations of spruce wood (Picea abies Karst.) during heat treatment," Wood Science and Technology 50(4), 715-726. DOI: 10.1007/s00226-016-0808-2

Biziks, V., Andersons, B., Beḷkova, L,., Kapača, E., and Militz, H. (2013). "Changes in the microstructure of birch wood after hydrothermal treatment," Wood Science and Technology 47, 717-735. DOI: 10.1007/s00226-013-0531-1

Boonstra, M. J., Rijsdijk, J. F., Sander, C., Kegel, E., Tjeerdsma, B., Militz, H., van Acker, J., and Stevens, M. (2006a). "Microstructural and physical aspects of heat treated wood. Part 1. Softwoods," Maderas. Ciencia y Tecnología 8(3), 193-208. DOI: $10.4067 / \mathrm{s} 0718-221 \times 2006000300006$

Boonstra, M. J., Rijsdijk, J. F., Sander, C., Kegel, E., Tjeerdsma, B., Militz, H., van Acker, J., and Stevens, M. (2006b). "Microstructural and physical aspects of heat treated wood. Part 2. Hardwoods," Maderas. Ciencia y Tecnología 8(3), 209-217. DOI: $10.4067 / \mathrm{s} 0718-221 \times 2006000300007$

Boonstra, M. J., van Acker, J., Tjeerdsma, B. F., and Kegel, E. V. (2007). "Strength properties of thermally modified softwoods and its relation to polymeric structural wood constituents," Annals of Forest Science 64(7), 679-690. DOI: 10.1051/forest: 2007048

Chaffey, N. (2002). "Wood microscopical techniques," in: Wood Formation in Trees, N. J. Chaffey (ed.), CRC Press, London, England, pp. 17-40.

Esteves, B., Velez Marques, A., Domingos, I., and Pereira, H. (2008). "Heat-induced colour changes of pine (Pinus pinaster) and eucalypt (Eucalyptus globulus) wood," Wood Science and Technology 42, 369-384. DOI: 10.1007/s00226-007-0157-2

Esteves, B., and Pereira, H. (2009). "Wood modification by heat treatment: A review," BioResources 4(1), 370-404.

Esteves, B., Nunes, L., Domingos, I., and Pereira, H. (2014). "Comparison between heat treated sapwood and heartwood from Pinus pinaster," Eur. J. Wood Wood Prod. 72(1), 53-60. DOI: 10.1007/s00107-013-0751-y 
Faraone, I., Russo, D., D’Auria, M., Bruno, M. R., Cetera, P., Todaro, L., and Milella, L. (2020). "Influence of thermal modification and extraction techniques on yield, antioxidant capacity and phytochemical profile of chestnut (Castanea sativa Mill.) wood," Holzforschung. DOI: 10.1515/hf-2020-0037

Gao, J. (2017). "Chemical and ultrastructural aspects of thermally modified wood with emphasis on durability," Diss. (sammanfattning/summary) Uppsala: Sveriges lantbruksuniv. Acta Universitatis Agriculturae Sueciae, 1652-6880; 2017:112 ISBN 978-91-7760-114-2 eISBN 978-91-7760-115-9

Herrera-Díaz, R., Sepúlveda-Villarroel, V., Torres-Mella, J., Salvo-Sepúlveda, L., LlanoPonte, R., Salinas-Lira, C., Peredo, M. A., and Ananías, R. A. (2019). "Influence of the wood quality and treatment temperature on the physical and mechanical properties of thermally modified radiata pine," European Journal of Wood and Wood Products 77, 661-671. DOI: 10.1007/s00107-019-01424-9

Hietala, S., Maunu, S. L., Sundholm, F., Jämsä, S., and Viitaniemi, P. (2002). "Structure of thermally modified wood studied by liquid state NMR measurements,"

Holzforschung 56(5), 522-528. DOI:10.1515/HF.2002.080

Hill, C. A. S. (2006). Wood Modification: Chemical, Thermal and Other Processes, John Wiley \& Sons, West Sussex, England.

Jiang, J., Wang, J., Zhang, X., and Wolcott, M. (2017). "Microstructure change in wood cell wall fracture from mechanical pretreatment and its influence on enzymatic hydrolysis," Industrial Crops and Products 97, 498-508. DOI: 10.1016/j.indcrop.2017.01.001

Kamdem, D. P., Pizzi, A., and Jermannaud, A. (2002). "Durability of heat-treated wood," Holz als Roh- und Werkstoff 60(1), 1-6. DOI: 10.1007/s00107-001-0261-1

Kekkonen, P. M., Telkki, V. V., and Jokisaari, J. (2010). "Effect of thermal modification on wood cell structures observed by pulsed-field-gradient stimulated-echo NMR," Journal of Physical Chemistry C 114(43), 18693-18697. DOI: 10.1021/jp1060304

Kubojima, Y., Okano, T., and Ohta, M. (2000). "Bending strength and toughness of heattreated wood," Journal of Wood Science 46(1), 8-15. DOI: 10.1007/bf00779547

Kymäläinen, M., Mlouka, S. B., Belt, T., Merk, V., Liljeström, V., Hänninen, T., Uimonen, T., Kostiainen, M., and Rautkari, L. (2018). "Chemical, water vapour sorption and ultrastructural analysis of Scots pine wood thermally modified in highpressure reactor under saturated steam," Journal of Materials Science 53(4), 30273037. DOI: 10.1007/s10853-017-1714-1

Lin, L., Yang, Y., Qium J., Luo, B., and Qin, L. (2017). "Effects of thermo-vacuum treatment on the anatomical structures of szemao pine wood and alder birch wood," Wood Research 62(5), 673-682.

Militz, H., and Altgen, M. (2014). "Processes and properties of thermally modified wood manufactured in Europe," in: Deterioration and Protection of Sustainable Biomaterials, T. P. Schultz, B. Goodell, and D. D. Nicholas (eds.), Oxford University Press, Washington D.C., USA, pp. 269-285.

Nopens, M., Riegler, M., Hansmann, C., and Krause, A. (2019). "Simultaneous change of wood mass and dimension caused by moisture dynamics," Sci. Rep. 9, 10309. DOI: 10.1038/s41598-019-46381-8

Nuopponen, M., Vuorinen, T., Jämsä, S., and Viitaniemi, P. (2005). “Thermal modifications in softwood studied by FT-IR and UV-resonance Raman spectroscopies," Journal of Wood Chemistry and Technology 24(1), 13-26. DOI: 10.1081/WCT-120035941 
Poncsák, S., Kocaefe, D., Bouazara, M., and Pichette, A. (2006). "Effect of high temperature treatment on the mechanical properties of birch (Betula papyrifera)," Wood Science and Technology 40, 647-663. DOI: 10.1007/s00226-006-0082-9

Redman, A. L., Bailleres, H., Turner, I., and Perré, P (2016). "Characterization of woodwater relationships and transverse anatomy and their relationship to drying degrade," Wood Sci. Technol. 50, 739-757. DOI: 10.1007/s00226-016-0818-0

Reiterer, A., and Tschegg, S. (2002). "The influence of moisture content on the mode I fracture behaviour of sprucewood," J. Mater. Sci. 37, 4487-4491.

Sandberg, D., Kutnar, A., and Mantanis, G. (2017). "Wood modification technologies - A review," iForest - Biogeosciences and Forestry 10(6), 895-908. DOI: 10.3832/ifor2380-010

Tasdemir, C., and Hiziroglu, S. (2014). "Measurement of various properties of Southern pine and aspen as function of heat treatment," Measurement 49, 91-98. DOI: 10.1016/j.measurement.2013.11.058

Tjeerdsma, B. F., and Militz, H. (2005). "Chemical changes in hydrothermal treated wood: FTIR analysis of combined hydrothermal and dry heat-treated wood," Holz als Roh- und Werkstoff 63(2), 102-111. DOI: 10.1007/s00107-004-0532-8

Uribe, B. E. B., and Ayala, O. A. (2015). "Characterization of three wood species (oak, teak and chanul) before and after heat treatment," Journal of the Indian Academy of Wood Science 12(1), 54-62. DOI: 10.1007/s13196-015-0144-4

Welzbacher, C. R., and Rapp, A. O. (2007). "Durability of thermally modified timber from industrial-scale processes in different use classes: Results from laboratory and field tests," Wood Material Science \& Engineering 2(1), 4-14. DOI: 10.1080/17480270701267504

Welzbacher, C. R., Rassam, G., Talaei, A., and Brischke, C. (2011). "Microstructure, strength and structural integrity of heat-treated beech and spruce wood," Wood Material Science \& Engineering 6(4), 219-227. DOI:

10.1080/17480272.2011.622411

Wentzel, M., Koddenberg, T., and Militz, H. (2020). "Anatomical characteristics of thermally modified Eucalyptus nitens wood in an open and closed reactor system," Wood Material Science \& Engineering 15(4), 223-228. DOI: 10.1080/17480272.2019.1572649

Yildiz, S., Gezer, E. D., and Yildiz, U. C. (2006). "Mechanical and chemical behavior of spruce wood modified by heat," Building and Environment 41(12), 1762-1766. DOI: 10.1016/j.buildenv.2005.07.017

Zhang, M., Smith, B. G., McArdle, B. H., Chavan, R. R., James, B. J., and Harris, P. J. (2018). "Dimensional changes of tracheids during drying of radiata pine (Pinus radiata D. Don) compression woods: A study using variable-pressure scanning electron microscopy (VP-SEM)," Plants 7(1), 14. DOI: 10.3390/plants7010014

Article submitted: August 11, 2020; Peer review completed: November 15, 2020; Revised version received and accepted: January 5, 2021; Published: January 10, 2021. DOI: 10.15376/biores.16.1.1523-1533 